\title{
The UPS: a promising target for breast cancer treatment Ko Sato ${ }^{1,2}$, Eeson Rajendra ${ }^{2}$ and Tomohiko Ohta*1
}

Address: ${ }^{1}$ Division of Breast and Endocrine Surgery, St Marianna University School of Medicine, Kawasaki, 216-8511, Japan and ${ }^{2} \mathrm{Hutchison} / \mathrm{MRC}$ Research Centre, Cambridge, CB2 OXZ, UK

Email: Tomohiko Ohta* - to@marianna-u.ac.jp

* Corresponding author

Published: 21 October 2008

BMC Biochemistry 2008, 9(Suppl I):S2 doi:I0.II86/I47I-209I-9-SI-S2

This article is available from: http://www.biomedcentral.com/I47I-209I/9/SI/S2

(c) 2008 Sato et al; licensee BioMed Central Ltd.

This is an open access article distributed under the terms of the Creative Commons Attribution License (http://creativecommons.org/licenses/by/2.0), which permits unrestricted use, distribution, and reproduction in any medium, provided the original work is properly cited.

\begin{abstract}
During the past decade, progress in endocrine therapy and the use of trastuzumab has significantly contributed to the decline in breast cancer mortality for hormone receptor-positive and ERBB2 (HER2)-positive cases, respectively. As a result of these advances, a breast cancer cluster with poor prognosis that is negative for the estrogen receptor (ESRI), the progesterone receptor (PRGR) and ERBB2 (triple negative) has come to the forefront of medical therapeutic attention. DNA microarray analyses have revealed that this cluster is phenotypically most like the basal-like breast cancer that is caused by deficiencies in the BRCAI pathways. To gain further improvements in breast cancer survival, new types of drugs might be required, and small molecules targeting the ubiquitin proteasome system have moved into the spotlight. The success of bortezomib in the treatment of multiple myeloma has sent encouraging signals that proteasome inhibitors could be used to treat other types of cancers. In addition, ubiquitin E3s involved in ESRI, ERBB2 or BRCAI pathways could be ideal targets for therapeutic intervention. This review summarizes the ubiquitin proteasome pathways related to these proteins and discusses the possibility of new drugs for the treatment of breast cancers.
\end{abstract}

Publication history: Republished from Current BioData's Targeted Proteins database (TPdb; http://www.targetedproteinsdb.com).

\section{Protein pathway involvement in disease The UPS in breast cancer}

The ubiquitin proteasome system (UPS) consists of several crucial enzymes: a ubiquitin-activating enzyme (E1), a ubiquitin-conjugating enzyme (E2), a ubiquitin ligase (E3) and the $26 \mathrm{~S}$ proteasome $[1,2]$. The $\mathrm{E} 3$ catalyzes the formation of polyubiquitin chains (and sometimes monoubiquitylation), utilizing ubiquitin monomers that have been activated by the E1 and E2 enzymes, and transfers them onto a specific substrate(s). Depending upon the type of ubiquitin chain, the ubiquitin modifications signal a variety of processes, including $26 \mathrm{~S}$ proteasomedependent degradation [3-5]. By contrast, ubiquitin mod- ifications are negatively controlled by deubiquitylation enzymes (DUBs) [6].

Remarkably, there are 1000 E3s, categorized into subfamilies based on the structure of their catalytic site, including 300-500 Cullin-ROC/Rbx complexes, 450 RING-type proteins, 40 HECT-type proteins and $20 \mathrm{U}$ box-type proteins. When comparing this with the $\sim 500$ mammalian protein kinases, it is easy to appreciate that the UPS contributes to most, if not all, cellular events. Therefore, it is realistic to anticipate major drug discoveries from this field, just like there have been in the kinase 
arena. Indeed, startling breakthroughs have been achieved recently with proteasome inhibitors.

\section{Estrogen receptors and the UPS}

The $\alpha$ subunit of the estrogen receptor (ESR1) is degraded by the UPS, and compounds inhibiting its degradation could accelerate breast cancer growth [7]. However, the mechanism underlying its proteolysis might not be straightforward as there are at least two pathways for degradation: ligand-independent and ligand-dependent. For ligand-independent degradation, unliganded ESR1 associates with a protein complex containing Hsc/Hsp70 (a protein chaperone) and STUB1 (CHIP), an E3 ligase containing a U-box. STUB1 preferentially recognizes misfolded ESR1 and targets this protein for ubiquitinmediated proteolysis. This pathway is important for the quality control of ESR1 $[8,9]$. Inhibition of this pathway could increase the active ESR1 pool. Alternatively, a dominant-negative effect could be induced by accumulation of misfolded ESR1.

Ligand-dependent degradation of ESR1 is mediated by different E3 ligases and is required for estrogen-induced transactivation. In HeLa cells expressing ESR1, treatment with MG132, a proteasome inhibitor, resulted in ESR1 stabilization but impaired ESR1-mediated transcription [10]. Cyclical recruitment of E3 ligases to ESR1 and binding of ESR1 to the proteasome is necessary for transcriptional activation of estrogen-responsive promoters $[11,12]$. During this process, the proteasome plays a central role in the clearance of ESR1-regulated transcription complexes, and inhibition of proteasomal activity prevents cycling of ESR1 onto promoters. Putative proteins involved in this process include: i) E3 ligases UBE3A (E6AP) [13,14], MDM2 [15] and TRI25 (EFP) [16]; ii) the 20 S catalytic proteasome subunit beta type-9 (PSB9; also known as LMP2) [12] and the $26 \mathrm{~S}$ protease regulatory subunit 8 (PRS8; also known as Rpt6/TRIP1/SUG1), which is a subunit of the $19 \mathrm{~S}$ regulatory cap of the proteasome [11]; and iii) NCOA1 (SRC), which interacts directly with PSB9 [12] and NCOA3 (AIB1), which interacts with UBE3A [17]. UBE3A and TRI25 are preferentially recruited to estrogen-liganded ESR1, whereas MDM2 preferentially, but not exclusively, associates with unliganded ESR1 $[11,16]$. NCOA3 is the p160 ESR1 transcriptional coactivator and is amplified or overexpressed in breast cancer. An Ncoa3 transgenic mouse shows a high incidence of tumors in multiple organs, including breast $[18,19]$.

\section{ERBB2, EGFR and UPS}

ERBB2 (HER2) and EGFR (ERBB1, HER1) are growth factor receptors (GFRs), members of the transmembrane receptor tyrosine kinase family, and are overexpressed in $25-30 \%$ and $7-20 \%$ of breast cancers, respectively [2022]. Similar to ESR1 ligand-dependent and -independent degradation, ubiquitylation is involved in the downregulation of GFRs. Ligand-dependent dimerization of EGFR increases tyrosine kinase activity and autophosphorylation of cytoplasmic tyrosine residues [23], and this enables interaction with the RING-domain-containing E3 ubiquitin-protein ligase CBL (c-CBL) in addition to downstream effectors SHC1 (SHC) and GRB2. CBL is phosphorylated by EGFR, which increases its ubiquitin ligase activity towards EGFR [24]. EGFR is then translocated to the endosomal compartment by SH3K1 (CIN85) and endophilins [25] and subsequently sorted for either recycling to the plasma membrane or destruction $[26,27]$. By contrast, phosphorylated ERBB2 only weakly associates with CBL and is resistant to CBL-induced downregulation [28]. In addition, ERBB2-EGFR heterodimerization blocks CBL association with EGFR and inhibits its lysosomal degradation, resulting in enhanced signaling [2831]. Interestingly, antibody-induced ERBB2 tyrosine phosphorylation at Tyr1112 mediates interaction of the receptor with $\mathrm{CBL}$, leading to receptor ubiquitylation and degradation [32]. By contrast, ligand-independent degradation of ERBB2 is mediated by STUB1 in collaboration with heatshock proteins Hsp70 and Hsp90 [33-36].

\section{BRCAI and basal-like cancer}

Gene-expression profiling identified basal-like breast cancer as an exceptional cluster with poor prognosis and a unique chemosensitivity. These cancers express basal/ myoepithelial cell markers such as cytokeratins 5/6, 14 and 17 or vimentin [37-39] but do not express ESR1, progesterone receptor (PRGR) or ERBB2 (triple negative) [37]. Approximately 15\% of sporadic breast cancers are characterized by this phenotype [37], but this particular cluster additionally possesses the dominant characteristics of aggressive breast cancers that are insensitive to both hormone therapy and trastuzumab (Herceptin, Genentech) [38], a humanized monoclonal antibody directed against ERBB2. Therefore, treatments that specifically target this subset of breast cancers could dramatically improve the overall prognosis for breast cancers. Interestingly, $80-90 \%$ of hereditary breast cancers with mutations in the gene encoding BRCA1 display a basal-like phenotype, suggesting that a deficiency in the BRCA1 pathway might cause this specific phenotype [39-43]. Indeed, BRCA1 dysfunction in sporadic basal-like cancers has been reported [44-46], and conditional deletion of exons encoding the C-terminus of BRCA1 in the mammary gland of mice results in basal-like cancer [47]. Thus, investigating the BRCA1 pathway could be an important approach for the treatment of basal-like cancer.

BRCA1 acts as a hub protein that coordinates a diverse range of cellular pathways to maintain genomic stability [48]. Figure 1 shows some representative functions of BRCA1. Many proteins whose mutation is implicated in 


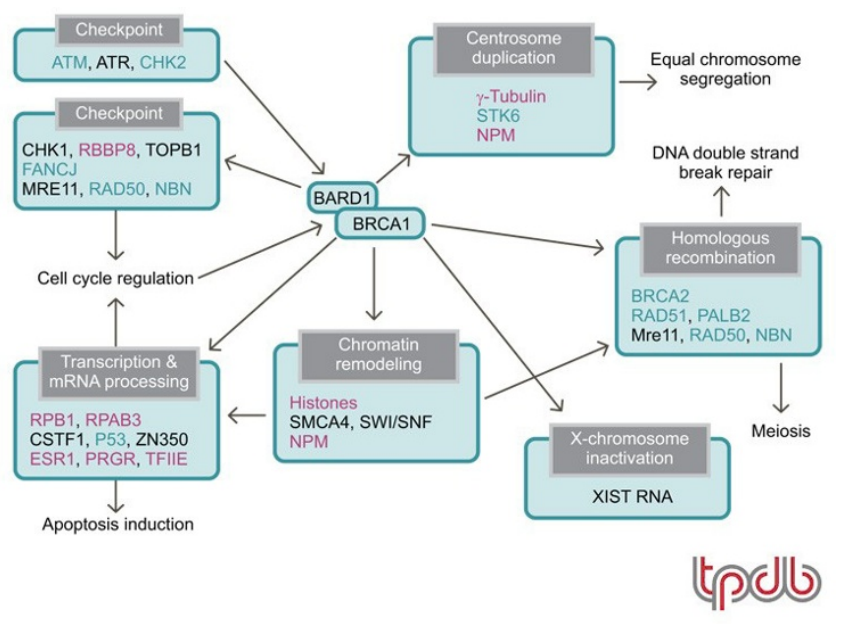

Figure I

Functional network of BRCAI and its interacting proteins that maintains genomic stability. Mauve: putative substrates for the BRCAI-BARDI E3 ligase. Aqua: proteins encoded by genes that cause familial breast cancer or increase the risk of getting breast cancer. Please note that Swiss-Prot entry name synonyms have been used in figure common synonyms are given in brackets: CHK2 (Chk2); CHKI (Chkl); RBBP8 (CtIP); TOPBI (TopBPI); FANCJ (BACHI/BRIPI); MREII (Mrel I); RAD50 (Rad50); NBN (NbsI); RPBI (Pol II [RPBI]); RPAB3 (RPB8); CSTFI (CstF50); P53 (p53); ZN350 (ZBRKI); ESRI (ER- $\alpha$ ); PRGR (PR); STK6 (Aurora A); NPM (NPMI/B23); BRCA2 (FANCDI); RAD5I (Rad5I); PALB2 (FANCN); SMCA4 (BRGI).

familial breast cancer, such as serine-protein kinase ATM $[49,50]$ and serine/threonine-protein kinase CHK2 [5153], are involved in this functional network. Mutation of the central BRCA1 gene results in $\sim 80 \%$ penetrance of breast cancer, and BRCA1 gene methylation or the accumulated dysfunctions of other proteins whose single mutation causes low penetrance are thought to result in sporadic breast cancer $[48,54]$. BRCA1 is a component of several different super-complexes, and, importantly, BRCA1 partners with BARD1 to form a RING heterodimer ubiquitin ligase [55,56] in most of these complexes [57]. This suggests that the BRCA1-BARD1 complex directs the ubiquitylation of distinct substrates within each complex. BRCA1-BARD1 catalyzes the formation of unconventional polyubiquitin chains that include Lys6-linked chains [58-60] or catalyzes the monoubiquitylation of some substrates [61-64]. The putative substrates of BRCA1 in each complex are shown in Figure 1. Histones [61,62], $\gamma$-tubulin [63] and ESR1 [64] are monoubiquitylated, whereas NPM1 [65], RPB1 [66,67], RBBP8 (CtIP) [68], RPAB3 (RPB8) [69], PRGR [70] and T2EA/T2EB (also known as general transcription factor IIE or TFIIE) [71] are polyubiquitylated and/or multiubiquitylated. Phosphor- ylated RPB1 and PRGR are ubiquitylated and degraded in vivo in the presence of BRCA1 $[66,70]$. However, there is presently no direct evidence supporting the notion that BRCA1-mediated ubiquitylation signals degradation. For the other polyubiquitylated substrates NPM1 [72], RBBP8 [68], RPAB3 [69] and T2EA/T2EB [71], as well as for BRCA1 autoubiquitylation [59], it has been proposed that the ubiquitylation is not a signal for degradation. Although the biochemical mechanism regarding how the ubiquitin modifications affect intermolecular functions remains to be clarified, some biological consequences of the modifications have been reported. RBBP8 ubiquitylation depends on the phosphorylation-mediated interaction between RBBP8 and BRCA1 BRCT domains (a phosphoserine/threonine binding motif), and ubiquitylated RBBP8 associates with chromatin after DNA damage to participate in G2/M checkpoint control [68]. RPAB3 is polyubiquitylated by BRCA1 after UV irradiation, and HeLa cells expressing a ubiquitin-resistant form of RPAB3 exhibit UV hypersensitivity [69]. BRCA1-mediated ubiquitylation of the T2EA subunit of T2EA/T2EB blocks the initiation of mRNA synthesis by preventing the association between the pre-initiation complex and both TFIIE and the general transcription factor IIH (TFIIH) [71].

\section{Disease models, knockouts and assays}

Basal-like cancer most closely resembles features of hereditary breast cancer associated with BRCA1 mutation. It also displays frequent mutations in the TP53 gene (encoding cellular tumor antigen P53). Based on this correlation, conditional mouse mutants with somatic deletion of Brca1 and Tp53 in mammary epithelium have been generated. Female mice of this strain show a high incidence of mammary tumors. Furthermore, the phenotype of these tumors mimics many aspects of human basal-like breast cancer [73]. More specifically, conditional mouse mutants with a deletion of the C-terminus of Brca1 and also heterozygous for a Tp53 mutation have also been generated. These show a high incidence of breast tumors that are similar to human basal-like cancer. [47] These mouse models could well prove useful for the study of basal-like cancer treatments.

It has recently been established that chimeric proteins containing the tyrosine kinase and RING domain of CBL and substituted Src-homology 2 domains from GRB2, from the P85 regulatory subunits of phosphoinositide 3kinase $(\mathrm{PI} 3 \mathrm{~K})$ or from SRC were capable of mediating ubiquitin-dependent proteolysis of ERBB2 (HER2) [74]. Although no physiological E3 ligases for the estrogen receptor (ESR1) and ERBB2 ubiquitylation have yet been identified, this model could prove useful for understanding ERBB2-positive cancer. Despite the fact that there are no mouse models of ERBB2 and ESR1 function in breast 
cancer, there is good potential for novel models to be generated for dissecting the roles of these two proteins.

\section{Disease targets and ligands \\ The UPS and proteasome inhibitors}

The first proteasome inhibitor that has come into clinical practice is bortezomib (Velcade, PS-341, Millennium) [75]. Approximately a third of relapsed, refractory multiple myeloma patients show a significant response to bortezomib [76], and the US FDA approved bortezomib for use as a therapy for multiple myeloma in 2003. Bortezomib inhibits proteasome function in a slowly reversible manner by means of an interaction between boronic acid at the C-terminus of bortezomib and an active threonine in the chymotryptic catalytic site of the $20 \mathrm{~S}$ proteasome [77]. The mechanisms underlying the therapeutic effect of bortezomib in multiple myeloma have been investigated intensively. Inhibition of the transcription factor NFKB by blocking the degradation of its inhibitory partner $\mathrm{I} \kappa \mathrm{B}$ is one such putative model. However, recent studies suggest that multiple factors might contribute to the efficacy of the drug [78]. An interesting recent study showed that inhibition of the 26S proteasome by MG132 causes a depletion of available nuclear ubiquitin because of the accumulation of nondegraded polyubiquitylated proteins in the cytosol. The depletion of free nuclear ubiquitin resulted in a loss of monoubiquitylated histones, and consequently this might have impaired many nuclear regulatory systems, including the DNA-damage responses $[79,80]$.

Clinical trials of bortezomib in many hematologic (e.g. a phase II trial on cutaneous T-cell lymphoma by Jonsson Comprehensive Cancer Center, NCT00182637) and nonhematologic malignancies (e.g. phase II trials on advanced bronchiolo-aveolar carcinoma [BAC] or adenocarcinoma by the California Cancer Consortium, NCT00118144, and on pleural mesothelioma by the Irish Clinical Oncology Research Group, NCT00513877) are ongoing. Thus far, bortezomib has failed to show a significant clinical effect on breast cancer. Although bortezomib was well tolerated, no responses were observed in 12 patients with aggressive metastatic breast cancers, with extremely poor prognoses, when used as a single agent [81]. However, the effect of combination therapy and the therapeutic effect for selected patients, such as those with tumors expressing a particular hormone receptor, ERBB2 (HER2) status or those in earlier stages of breast cancer, remain to be determined.

There are increasing numbers of small molecules that target the UPS. The UPS Patent Portfolio table and UPS Drugs \& Biologicals table on the Targeted Proteins database show the patents and drugs in development or on the market (and the associated organizations and companies) designed to inhibit the UPS that might be useful in breast cancer therapy. An orally active proteasome inhibitor salinosporamide A (NPI0052, Nereus), a natural product derived from a marine actinomycete, resembles lactacystin and irreversibly targets the proteasome [82,83,72]. Epoxomicin and eponemicin are epoxyketone-containing natural products that exhibit antitumor activity $[84,85]$. Epoxomicin, currently the most specific proteasome inhibitor, reacts irreversibly with the chymotrypsin-like site, whereas the less-potent epoxyketone eponemicin reacts with both the caspase-like and chymotrypsin-like sites of the proteasome [86-88]. PR171 (carfilzomib, Proteolix), a synthetic derivative of epoxomicin, has been shown recently to have antiproliferative and proapoptotic effects on primary human acute myeloid leukemia cells [89].

\section{Estrogen receptors and the UPS}

Many anti-breast cancer drugs are involved in degradation of the estrogen receptor (ESR1) [90]. The pure antagonist fulvestrant (ICI 182780, AstraZeneca) and RU58668 promote degradation of ESR1, whereas 4-hydroxy-tamoxifen does not [91]. Fulvestrant removes ESR1 from cyclic recruitment to its target promoters by direct targeting of ESR1 to the proteasome without associated transcription [11]. NCOA3 (AIB1) also induces agonist-induced, but not antagonist-induced, degradation of ESR1. Therefore, the suppression of NCOA3 that results in inhibition of estrogen-induced degradation of ESR1, but not degradation induced by fulvestrant or GW5638 [17], could have additional clinical effects for ESR1-positive breast cancer. Other compounds that induce degradation of ESR1 include 2,3,7,8-tetrachlorodibenzo-p-dioxin (TCDD), a ligand of the aryl hydrocarbon receptor (AHR) [92], and PPARG agonists ciglitazone and 15-deoxy-delta 12,14prostaglandin J2 [93].

Although these existing drugs have not been designed to modify the UPS, it is possible that they function primarily through UPS modulation. In this regard, revealing the precise mechanisms of degradation of ESR1 with respect to the UPS might further improve the effectiveness of such compounds for the treatment of breast cancer. Compounds that affect the interactions of E3 ligases, coactivators and proteasome subunits in ESR1-regulated complexes on promoters could work as anti-breast cancer agents.

\section{ERBB2, EGFR and the UPS}

As mentioned previously, ligand-independent degradation of ERBB2 is mediated by STUB1 (CHIP) in collaboration with Hsp70 and Hsp90 [33-36]. Therefore, acceleration of this pathway might have additive anticancer activity when introduced with trastuzumab. The potent anticancer agent geldanamycin, a benzoquinone 
ansamycin that binds to Hsp90, is one such candidate $[33,34]$. In addition, the STUB1-dependent degradation pathway of ERBB2 can be stimulated by tyrosine kinase inhibitors such as CI1033 (Pfizer) [35]. CI1033 and geldanamycin additively inhibit tumor cell growth.

Thus, downregulation of ERBB2 by means of acceleration of the UPS is of crucial importance to breast cancer treatment. Interestingly, however, the proteasome inhibitor bortezomib has an additive or synergistic effect with trastuzumab in the induction of apoptosis in ERBB2-positive breast cancer cell lines [94]. It is likely that inhibition of other UPS pathways contributes to this effect. Alternatively, it could be caused by a depletion of available nuclear ubiquitin due to the accumulation of nondegraded polyubiquitinated proteins, as mentioned previously $[79,80]$.

Targets downstream of ERBB2 could also be affected by the UPS. BIRC5 (also known as survivin), an anti-apoptotic protein, is expressed only in tumors. Expression of BIRC5 is associated with a poor prognosis in a variety of malignancies, including breast cancer $[95,96]$. Recent studies revealed that BIRC5 is regulated by ERBB2 and ERBB3 but not by EGFR [97]. Interrupting the ERBB2ERBB3 heterodimer using lapatinib (GW572016, GlaxoSmithKline), a potent small-molecule inhibitor of EGFR and ERBB2 tyrosine kinases, leads to proteasomal degradation of BIRC5 and induces apoptosis both in breast cancer cell lines overexpressing ERBB2 and in primary tumors [97]. Understanding the mechanisms that protect ERBB2overexpressing cancer cells from apoptosis might result in new targets for therapeutic intervention.

\section{New frontiers in drug discovery}

The therapeutic effect of proteasome inhibitors on breast cancer remains to be determined but is greatly anticipated. Additionally, interest is focused on the discovery of other potent anticancer drugs that affect substrate ubiquitylation by E3 ligases as well as their deubiquitylation catalyzed by DUB enzymes. Because inhibition of the proteasome, whose activity is crucial for all cell types, imparts such a specific clinical effect, inhibiting the catalytic site of E3 ligases that regulate a broad range of cellular processes, for example the RBX1 (ROC1) RING finger subunit of Cullin-based E3 complexes [98,99], could be equally valuable. Alternatively, E3 ligases found to be oncogenes or tumor suppressor genes that regulate more restricted pathways could be promising targets for smallmolecule inhibitors and activators, respectively, with fewer side effects [100]. The following sections describe such specific pathways that link directly to the breast cancer clinic.

\section{Estrogen receptors and the UPS}

Progress in hormone therapy, including aromatase inhibitors and the gonadotrophin-releasing hormone agonist goserelin, has been a major contribution to the recent improvements in breast cancer prognosis. As there already exist several effective hormone therapy agents, it might be conjectured that discovering additional drugs for the same pathway is not necessary. However, approximately half of hormone receptor-positive breast cancers do not respond sufficiently to the current hormone therapies [101], and therefore alternative drugs free from cross-tolerance are needed. Compounds targeting the UPS in hormone receptor signaling could be one such alternative.

\section{ERBB2, EGFR and UPS}

Trastuzumab prolongs the survival of patients with metastatic ERBB2 (HER2)-positive breast cancer and leads to dramatic improvements in prognosis when used in adjuvant therapy [102]. Indeed, trastuzumab has switched ERBB2-positive breast cancer from being a subset with the worst prognosis to one that is curable with existing therapy [102]. However, even in a subset of patients with highly ERBB2-positive tumors, the response rate to trastuzumab is still limited, and alternative compounds that target the ERBB2 pathway could have additive or synergistic roles. The UPS is definitely one such candidate. In addition to ERBB2, EGFR is overexpressed in basal-like breast cancer and is a possible target for new anti-breast cancer reagents.

\section{BRCAI and basal-like cancer}

Although the significance of the E3 activity of BRCA1 in the BRCA1 functional network (Figure 1) is only partially understood, it is obvious that its activity is crucial in the prevention of a certain subset of breast cancers $[56,103$ 105]. In terms of the potential for targeting this activity for breast cancer therapy, tumor suppressors such as BRCA1 are not ideal targets for therapy because small molecule activators can be more difficult to produce than small molecule inhibitors. This is absolutely true for the treatment of breast cancer caused by BRCA1 gene mutations. However, if the breast cancer results from other factors that cause downregulation of BRCA1 - for instance, in the case of sporadic basal-like breast cancer - small molecules that activate BRCA1 E3 activity could be successful.

\section{List of abbreviations used}

DUB: deubiquitylation enzyme; GFR: growth factor receptor; PI3K: phosphoinositide 3-kinase; UPS: ubiquitin proteasome system.

\section{Competing interests}

T. Ohta is the author of two patents: 
1) Ohta T. Carcinostatic method using BRCA1-BARD1 pathway. WO2005073379 (08/11/2005).

2) Ohta T and Wu W. A method for the ubiquitination of common subunits of RNA polymerases. WO2007046538 (04/26/2007).

\section{Acknowledgements}

This article has been published as part of BMC Biochemistry Volume 9 Supplement I, 2008: Ubiquitin-Proteasome System in Disease Part 2. The full contents of the supplement are available online at http://www.biomedcen tral.com $/|47|-209 \mid / 9$ ? issue=SI.

Additional TPdb reviews on the ubiquitin-proteasome system are also available in BMC Biochemistry - see Volume 8 Suppl I http://www.biomedcen tral.com $/|47|-209 \mid / 8$ ? issue=SI.

\section{References}

I. Hershko A, Ciechanover A: The ubiquitin system. Annu Rev Biochem 1998, 67:425-79.

2. Pickart CM, Eddins MJ: Ubiquitin: structures, functions, mechanisms. Biochim Biophys Acta 2004, I 695(I-3):55-72.

3. Pickart CM: Back to the future with ubiquitin. Cell 2004, I 16:181-90.

4. Mukhopadhyay D, Riezman H: Proteasome-independent functions of ubiquitin in endocytosis and signaling. Science 2007, 3 I5(5809):201-5.

5. Ohta T, Fukuda M: Ubiquitin and breast cancer. Oncogene 2004, 23(I I):2079-88.

6. Nijman SM, Luna-Vargas MP, Velds A, Brummelkamp TR, Dirac AM, Sixma TK, Bernards R: A genomic and functional inventory of deubiquitinating enzymes. Cell 2005, I 23(5):773-86.

7. Nawaz Z, Lonard DM, Dennis AP, Smith CL, O'Malley BW: Proteasome-dependent degradation of the human estrogen receptor. Proc Natl Acad Sci USA 1999, 96(5): 1858-62.

8. Tateishi Y, Kawabe Y, Chiba T, Murata S, Ichikawa K, Murayama A, Tanaka K, Baba T, Kato S, Yanagisawa J: Ligand-dependent switching of ubiquitin-proteasome pathways for estrogen receptor. $E M B O$ J 2004, 23(24):4813-23.

9. Fan M, Park A, Nephew KP: CHIP (carboxyl terminus of Hsc70interacting protein) promotes basal and geldanamycininduced degradation of estrogen receptor-alpha. Mol Endocrinol 2005, I9(I 2):2901-14.

10. Lonard DM, Nawaz Z, Smith CL, O'Malley BW: The 265 proteasome is required for estrogen receptor-alpha and coactivator turnover and for efficient estrogen receptor-alpha transactivation. Mol Cell 2000, 5(6):939-48.

II. Reid G, Hubner MR, Metivier R, Brand H, Denger S, Manu D, Beaudouin J, Ellenberg J, Gannon F: Cyclic, proteasome-mediated turnover of unliganded and liganded ERalpha on responsive promoters is an integral feature of estrogen signaling. Mol Cell 2003, I I(3):695-707.

12. Zhang H, Sun L, Liang J, Yu W, Zhang Y, Wang Y, Chen Y, Li R, Sun $X$, Shang $Y$ : The catalytic subunit of the proteasome is engaged in the entire process of estrogen receptor-regulated transcription. EMBO J 2006, 25( I 8):4223-33.

13. Nawaz Z, Lonard DM, Smith CL, Lev-Lehman E, Tsai SY, Tsai MJ, O'Malley BW: The Angelman syndrome-associated protein, E6-AP, is a coactivator for the nuclear hormone receptor superfamily. Mol Cell Biol 1999, I 9(2): I I82-9.

14. Li L, Li Z, Howley PM, Sacks DB: E6AP and calmodulin reciprocally regulate estrogen receptor stability. J Biol Chem 2006, 28 I (4): 1978-85.

15. Saji S, Okumura N, Eguchi H, Nakashima S, Suzuki A, Toi M, Nozawa Y, Saji S, Hayashi S: MDM2 enhances the function of estrogen receptor alpha in human breast cancer cells. Biochem Biophys Res Commun 200I, 28 I(I):259-65.

16. Nakajima A, Maruyama S, Bohgaki M, Miyajima N, Tsukiyama T, Sakuragi N, Hatakeyama S: Ligand-dependent transcription of estrogen receptor alpha is mediated by the ubiquitin ligase EFP. Biochem Biophys Res Commun 2007, 357(I):245-5I.
17. Shao W, Keeton EK, McDonnell DP, Brown M: Coactivator AIB I links estrogen receptor transcriptional activity and stability. Proc Natl Acad Sci USA 2004, I 0 I (32): I I 599-604.

18. Torres-Arzayus MI, Font de Mora J, Yuan J, et al.: High tumor incidence and activation of the PIJK/AKT pathway in transgenic mice define AIB I as an oncogene. Cancer Cell 2004, 6:263-74.

19. Torres-Arzayus MI, Yuan J, DellaGatta JL, Lane H, Kung AL, Brown M: Targeting the AIB I oncogene through mammalian target of rapamycin inhibition in the mammary gland. Cancer Res 2006, 66(23): I I38|-8.

20. Harari D, Yarden Y: Molecular mechanisms underlying ErbB2/ HER2 action in breast cancer. Oncogene 2000, I9(53):6102-6II4.

21. Bhargava R, Gerald WL, Li AR, Pan Q, Lal P, Ladanyi M, Chen B: EGFR gene amplification in breast cancer: correlation with epidermal growth factor receptor $m R N A$ and protein expression and HER-2 status and absence of EGFR-activating mutations. Mod Pathol 2005, I 8(8): I027-33.

22. Park K, Han S, Shin E, Kim HJ, Kim JY: EGFR gene and protein expression in breast cancers. Eur J Surg Oncol 2007, 33(8):956-60.

23. Olayioye MA, Neve RM, Lane HA, Hynes NE: The ErbB signaling network: receptor heterodimerization in development and cancer. EMBO J 2000, I9(13):3159-67.

24. Mosesson Y, Shtiegman K, Katz M, Zwang Y, Vereb G, Szollosi J, Yarden $Y$ : Endocytosis of receptor tyrosine kinases is driven by monoubiquitylation, not polyubiquitylation. I Biol Chem 2003, 278(24):21323-6.

25. Dikic I, Giordano S: Negative receptor signalling. Curr Opin Cell Biol 2003, I 5(2): I 28-35.

26. Bucci C, Thomsen P, Nicoziani P, McCarthy J, van Deurs B: Rab7: a key to lysosome biogenesis. Mol Biol Cell 2000, I I (2):467-80.

27. de Renzis S, Sonnichsen B, Zerial M: Divalent Rab effectors regulate the sub-compartmental organization and sorting of early endosomes. Nat Cell Biol 2002, 4(2): I24-33.

28. Muthuswamy SK, Gilman M, Brugge JS: Controlled dimerization of ErbB receptors provides evidence for differential signaling by homo- and heterodimers. Mol Cell Biol I999, I9( I 0):6845-57.

29. Graus-Porta D, Beerli RR, Daly JM, Hynes NE: ErbB-2, the preferred heterodimerization partner of all ErbB receptors, is a mediator of lateral signaling. EMBO J 1997, I 6(7): 1647-55.

30. Levkowitz G, Waterman H, Zamir E, Kam Z, Oved S, Langdon WY, Beguinot L, Geiger B, Yarden Y: c-Cbl/Sli-I regulates endocytic sorting and ubiquitination of the epidermal growth factor receptor. Genes Dev 1998, I2(23):3663-74.

31. Lenferink AE, Pinkas-Kramarski R, Poll ML van de, van Vugt MJ, Klapper LN, Tzahar E, Waterman H, Sela M, van Zoelen EJ, Yarden Y: Differential endocytic routing of homo- and hetero-dimeric ErbB tyrosine kinases confers signaling superiority to receptor heterodimers. EMBO J 1998, I 7( I 2):3385-97.

32. Klapper LN, Waterman H, Sela M, Yarden Y: Tumor-inhibitory antibodies to HER-2/ErbB-2 may act by recruiting c-Cbl and enhancing ubiquitination of HER-2. Cancer Res 2000, 60(13):3384-8.

33. Zhou P, Fernandes N, Dodge IL, Reddi AL, Rao N, Safran H, DiPetrillo TA, Wazer DE, Band V, Band H: ErbB2 degradation mediated by the co-chaperone protein CHIP. J Biol Chem 2003, 278( 16): 13829-37.

34. Xu W, Marcu M, Yuan X, Mimnaugh E, Patterson C, Neckers L: Chaperone-dependent E3 ubiquitin ligase CHIP mediates a degradative pathway for c-ErbB2/Neu. Proc Natl Acad Sci USA 2002, 99(20): 12847-52.

35. Citri A, Alroy I, Lavi S, Rubin C, Xu W, Grammatikakis N, Patterson C, Neckers L, Fry DW, Yarden Y: Drug-induced ubiquitylation and degradation of ErbB receptor tyrosine kinases: implications for cancer therapy. EMBO J 2002, 2 I (I 0):2407-I7.

36. Connell P, Ballinger CA, Jiang J, Wu Y, Thompson LJ, Hohfeld J, Patterson $\mathrm{C}$ : The co-chaperone $\mathrm{CHIP}$ regulates protein triage decisions mediated by heat-shock proteins. Nat Cell Biol 200I, 3(1):93-96.

37. Perou CM, Sorlie T, Eisen MB, Rijn M van de, Jeffrey SS, Rees CA, Pollack JR, Ross DT, Johnsen H, Akslen LA, et al.: Molecular portraits of human breast tumours. Nature 2000, 406(6797):747-752.

38. Tanner M, Kapanen Al, Junttila T, Raheem O, Grenman S, Elo J, Elenius $\mathrm{K}$, Isola J: Characterization of a novel cell line established 
from a patient with Herceptin-resistant breast cancer. Mol Cancer Ther 2004, 3(12): I585-92.

39. Sorlie T, Tibshirani R, Parker J, Hastie T, Marron JS, Nobel A, Deng S, Johnsen H, Pesich R, Geisler S, et al.: Repeated observation of breast tumor subtypes in independent gene expression data sets. Proc Natl Acad Sci USA 2003, I 00( I 4):84| 8-8423.

40. Foulkes WD, Stefansson IM, Chappuis PO, Begin LR, Goffin JR, Wong N, Trudel M, Akslen LA: Germline BRCAI mutations and a basal epithelial phenotype in breast cancer. J Natl Cancer Inst 2003, 95(19): | 482-| 485.

41. Lakhani SR, Reis-Filho JS, Fulford L, Penault-Llorca F, Vijver M van der, Parry S, Bishop T, Benitez J, Rivas C, Bignon YJ, et al: Prediction of BRCAI status in patients with breast cancer using estrogen receptor and basal phenotype. Clin Cancer Res 2005, I I(I4):5I75-5I80.

42. Honrado E, Osorio A, Palacios J, Benitez J: Pathology and gene expression of hereditary breast tumors associated with BRCA1, BRCA2 and CHEK2 gene mutations. Oncogene 2006, 25(43):5837-45.

43. Turner $\mathrm{N}$, Tutt $\mathrm{A}$, Ashworth $\mathrm{A}$ : Hallmarks of $B$ RCAness in sporadic cancers. Nat Rev Cancer 2004, 4:8I4-8I9.

44. Staff S, Isola J, Tanner M: Haplo-insufficiency of BRCAI in sporadic breast cancer. Cancer Res 2003, 63( 16):4978-4983.

45. Turner NC, Reis-Filho JS, Russell AM, Springall RJ, Ryder K, Steele D, Savage K, Gillett CE, Schmitt FC, Ashworth A, et al.: BRCAI dysfunction in sporadic basal-like breast cancer. Oncogene 2007, 26(I4):2|26-2|32.

46. Richardson AL, Wang ZC, De Nicolo A, Lu X, Brown M, Miron A Liao X, Iglehart JD, Livingston DM, Ganesan S: $\mathbf{X}$ chromosomal abnormalities in basal-like human breast cancer. Cancer Cell 2006, 9(2): $121-32$

47. McCarthy A, Savage K, Gabriel A, Naceur C, Reis-Filho JS, Ashworth $A$ : A mouse model of basal-like breast carcinoma with metaplastic elements. J Pathol 2007, 2 I I (4):389-98.

48. Zheng L, Li S, Boyer TG, Lee WH: Lessons learned from BRCAI and BRCA2. Oncogene 2000, 19(53):6159-75.

49. Swift M, Morrell D, Cromartie E, Chamberlin AR, Skolnick MH, Bishop DT: The incidence and gene frequency of ataxia-telangiectasia in the United States. Am J Hum Genet 1986, 39(5):573-83.

50. Ahmed M, Rahman N: ATM and breast cancer susceptibility. Oncogene 2006, 25(43):5906-II.

51. Meijers-Heijboer H, Ouweland A van den, Klijn J, Wasielewski M, de Snoo A, Oldenburg R, Hollestelle A, Houben M, Crepin E, van VeghelPlandsoen M, Elstrodt F, van Duijn C. Bartels C. Meijers C, Schutte M, McGuffog L, Thompson D, Easton D, Sodha N, Seal S, Barfoot R, Mangion J, Chang-Claude J, Eccles D, Eeles R, Evans DG, Houlston R, Murday V, Narod S, Peretz T, Peto J, Phelan C, Zhang HX, Szabo C, Devilee P, Goldgar D, Futreal PA, Nathanson KL, Weber B, Rahman N, Stratton MR: CHEK2-Breast Cancer Consortium. Low-penetrance susceptibility to breast cancer due to CHEK2(*) I I 00 delC in noncarriers of BRCAI or BRCA2 mutations. Nat Genet 2002, 3 I ( I):55-9.

52. CHEK2 Breast Cancer Case-Control Consortium: CHEK2*1100 delC and susceptibility to breast cancer: a collaborative analysis involving 10,860 breast cancer cases and 9,065 controls from 10 studies. Am J Hum Genet 2004, 74(6): I I75-82.

53. Walsh T, Casadei S, Coats KH, Swisher E, Stray SM, Higgins J, Roach KC, Mandell J, Lee MK, Ciernikova S, Foretova L, Soucek P, King MC Spectrum of mutations in BRCAI, BRCA2, CHEK2, and TP53 in families at high risk of breast cancer. JAMA 2006 295( I 2): 1379-88.

54. Dobrovic A, Simpfendorfer D: Methylation of the BRCAI gene in sporadic breast cancer. Cancer Res 1997, 57( 16):3347-50.

55. Wu LC, Wang ZW, Tsan JT, Spillman MA, Phung A, Xu XL, Yang MC, Hwang $L Y$, Bowcock AM, Baer R: Identification of a RING protein that can interact in vivo with the BRCAI gene product. Nat Genet 1996, 14(4):430-40.

56. Hashizume R, Fukuda M, Maeda I, Nishikawa H, Oyake D, Yabuki $Y$, Ogata $\mathrm{H}$, Ohta T: The RING heterodimer BRCAI-BARDI is a ubiquitin ligase inactivated by a breast cancer-derived mutation. J Biol Chem 200I, 276( ( 8): I4537-40.

57. Greenberg RA, Sobhian B, Pathania S, Cantor SB, Nakatani Y, Livingston DM: Multifactorial contributions to an acute DNA damage response by BRCAI/BARDI-containing complexes. Genes Dev 2006, 20(I):34-46.
58. Wu-Baer F, Lagrazon K, Yuan W, Baer R: The BRCAI/BARDI heterodimer assembles polyubiquitin chains through an unconventional linkage involving lysine residue $\mathrm{K} 6$ of ubiquitin. I Biol Chem 2003, 278(37):34743-6.

59. Nishikawa H, Ooka S, Sato K, Arima K, Okamoto J, Klevit RE, Fukuda $M$, Ohta $T$ : Mass spectrometric and mutational analyses reveal Lys-6-linked polyubiquitin chains catalyzed by BRCAI-BARDI ubiquitin ligase. J Biol Chem 2004, 279(6):3916-24.

60. Morris JR, Solomon E: BRCAI: BARDI induces the formation of conjugated ubiquitin structures, dependent on $\mathrm{K} 6$ of ubiquitin, in cells during DNA replication and repair. Hum Mol Genet 2004, 13(8):807-17.

61. Chen A, Kleiman FE, Manley JL, Ouchi T, Pan ZQ: Autoubiquitination of the BRCAI-BARDI RING ubiquitin ligase. J Biol Chem 2002, 277(24):22085-92.

62. Mallery DL, Vandenberg C), Hiom K: Activation of the E3 ligase function of the BRCAI/BARDI complex by polyubiquitin chains. EMBO J 2002, 21 (24):6755-62.

63. Starita LM, Machida Y, Sankaran S, Elias JE, Griffin K, Schlegel BP, Gygi SP, Parvin JD: BRCAI-dependent ubiquitination of gammatubulin regulates centrosome number. Mol Cell Biol 2004, 24(19):8457-66.

64. Eakin CM, Maccoss MJ, Finney GL, Klevit RE: Estrogen receptor alpha is a putative substrate for the BRCAI ubiquitin ligase. Proc Natl Acad Sci USA 2007, 104( (14):5794-9.

65. Sato K, Hayami R, Wu W, Nishikawa T, Nishikawa H, Okuda Y, Ogata H, Fukuda M, Ohta T: Nucleophosmin/B23 is a candidate substrate for the BRCAI-BARDI ubiquitin ligase. J Biol Chem 2004, 279(30):30919-22.

66. Kleiman FE, Wu-Baer F, Fonseca D, Kaneko S, Baer R, Manley JL: BRCAI/BARDI inhibition of mRNA 3' processing involves targeted degradation of RNA polymerase II. Genes Dev 2005 , 19(10): 1227-37.

67. Starita LM, Horwitz AA, Keogh MC, Ishioka C, Parvin JD, Chiba N: BRCAI/BARDI ubiquitinate phosphorylated RNA polymerase II. J Biol Chem 2005, 280(26):24498-505.

68. Yu X, Fu S, Lai M, Baer R, Chen J: BRCAI ubiquitinates its phosphorylation-dependent binding partner CtIP. Genes Dev 2006, 20(I3): $172 \mid-6$.

69. Wu W, Nishikawa H, Hayami R, Sato K, Honda A, Aratani S, Nakajima $T$, Fukuda $M$, Ohta $T$ : BRCAl ubiquitinates RPB8 in response to DNA damage. Cancer Res 2007, 67(3):95I-8.

70. Poole AJ, Li Y, Kim Y, Lin SC, Lee WH, Lee EY: Prevention of Brcal-mediated mammary tumorigenesis in mice by a progesterone antagonist. Science 2006, 3 |4(5804): |467-70.

7I. Horwitz AA, Affar el B, Heine GF, Shi Y, Parvin JD: A mechanism for transcriptional repression dependent on the BRCAI E3 ubiquitin ligase. Proc Natl Acad Sci USA 2007, 104(16):66I4-9.

72. Joazeiro CA, Anderson KC, Hunter T: Proteasome inhibitor drugs on the rise. Cancer Res 2006, 66 ( I6):7840-2.

73. Liu X, Holstege H, Gulden $H$ van der, Treur-Mulder M, Zevenhoven J. Velds A, Kerkhoven RM, van Vliet MH, Wessels LF, Peterse JL, Berns A, Jonkers J: Somatic loss of BRCAI and p53 in mice induces mammary tumors with features of human BRCAImutated basal-like breast cancer. Proc Natl Acad Sci USA 2007. 104(29): $1211 \mid-6$

74. Li X, Shen L, Zhang J, Su J, Shen L, Liu X, Han H, Han W, Yao L: Degradation of HER2 by Cbl-based chimeric ubiquitin ligases. Cancer Res 2007, 67( 18):8716-24.

75. Hideshima T, Richardson P, Chauhan D, Palombella VJ, Elliott PJ, Adams J, Anderson KC: The proteasome inhibitor PS-34I inhibits growth, induces apoptosis, and overcomes drug resistance in human multiple myeloma cells. Cancer Res 200I, 6 I (7):307I-6.

76. Richardson PG, Barlogie B, Berenson J, Singhal S, Jagannath S, Irwin D, Rajkumar SV, Srkalovic G, Alsina M, Alexanian R, Siegel D, Orlowski RZ, Kuter D, Limentani SA, Lee S, Hideshima T, Esseltine DL, Kauffman M, Adams J, Schenkein DP, Anderson KC: A phase 2 study of bortezomib in relapsed, refractory myeloma. $N$ Engl J Med 2003, 348(26):2609-17.

77. Adams J: The proteasome: structure, function, and role in the cell. Cancer Treat Rev 2003, 29(Suppl I):3-9.

78. Hideshima T, Chauhan D, Richardson P, Mitsiades C, Mitsiades N, Hayashi T, Munshi N, Dang L, Castro A, Palombella V, Adams ], 
Anderson KC: NF-kappa B as a therapeutic target in multiple myeloma. J Biol Chem 2002, 277(19):16639-47.

79. Dantuma NP, Groothuis TA, Salomons FA, Neefjes J: A dynamic ubiquitin equilibrium couples proteasomal activity to chromatin remodeling. J Cell Biol 2006, 173(I):19-26.

80. Mailand N, Bekker-Jensen S, Faustrup H, Melander F, Bartek J, Lukas C, Lukas J: RNF8 ubiquitylates histones at DNA double-strand breaks and promotes assembly of repair proteins. Cell 2007, | 3 I(5):887-900.

81. Yang CH, Gonzalez-Angulo AM, Reuben JM, Booser DJ, Pusztai L, Krishnamurthy S, Esseltine D, Stec J, Broglio KR, Islam R, Hortobagyi GN, Cristofanilli M: Bortezomib (VELCADE) in metastatic breast cancer: pharmacodynamics, biological effects, and prediction of clinical benefits. Ann Oncol 2006, I7(5):8I3-7.

82. Feling RH, Buchanan GO, Mincer TJ, Kauffman CA, Jensen PR, Fenical W: Salinosporamide A: a highly cytotoxic proteasome inhibitor from a novel microbial source, a marine bacterium of the new genus salinospora. Angew Chem Int Ed Engl 2003, 42(3):355-7.

83. Chauhan D, Catley L, Li G, Podar K, Hideshima T, Velankar M, Mitsiades C, Mitsiades N, Yasui H, Letai A, Ovaa H, Berkers C, Nicholson B, Chao TH, Neuteboom ST, Richardson P, Palladino MA, Anderson $\mathrm{KC}$ : A novel orally active proteasome inhibitor induces apoptosis in multiple myeloma cells with mechanisms distinct from Bortezomib. Cancer Cell 2005, 8(5):407-19.

84. Hanada M, Sugawara K, Kaneta K, Toda S, Nishiyama Y, Tomita K, Yamamoto H, Konishi M, Oki T: Epoxomicin, a new antitumor agent of microbial origin. J Antibiot (Tokyo) I992, 45(I I): I 746-52.

85. Sugawara K, Hatori M, Nishiyama $Y$, Tomita K, Kamei H, Konishi M, Oki T: Eponemycin, a new antibiotic active against $B 16$ melanoma. I. Production, isolation, structure and biologica activity. J Antibiot (Tokyo) 1990, 43(I):8-I8.

86. Sin N, Kim KB, Elofsson M, Meng L, Auth H, Kwok BH, Crews CM: Total synthesis of the potent proteasome inhibitor epoxomicin: a useful tool for understanding proteasome biology. Bioorg Med Chem Lett 1999, 9(15):2283-8.

87. Meng L, Kwok BH, Sin N, Crews CM: Eponemycin exerts its antitumor effect through the inhibition of proteasome function. Cancer Res 1999, 59:2798-280I.

88. Meng L, Mohan R, Kwok BH, Elofsson M, Sin N, Crews CM: Epoxomicin, a potent and selective proteasome inhibitor, exhibits in vivo antiinflammatory activity. Proc Natl Acad Sci USA 1999, 96(18): 10403-8

89. Stapnes C, Doskeland AP, Hatfield K, Ersvaer E, Ryningen A, Lorens JB, Gjertsen BT, Bruserud O: The proteasome inhibitors bortezomib and PR-I7I have antiproliferative and proapoptotic effects on primary human acute myeloid leukaemia cells. $\mathrm{Br}$ J Haematol 2007, I36(6):8|4-28.

90. Wijayaratne AL, McDonnell DP: The human estrogen receptoralpha is a ubiquitinated protein whose stability is affected differentially by agonists, antagonists, and selective estrogen receptor modulators. J Biol Chem 200I, 276(38):35684-92.

91. Marsaud V, Gougelet A, Maillard S, Renoir JM: Various phosphorylation pathways, depending on agonist and antagonist binding to endogenous estrogen receptor alpha (ERalpha), differentially affect ERalpha extractability, proteasomemediated stability, and transcriptional activity in human breast cancer cells. Mol Endocrinol 2003, I7(I0):2013-27.

92. Wormke M, Stoner M, Saville B, Walker K, Abdelrahim M, Burghardt $R$, Safe $S$ : The aryl hydrocarbon receptor mediates degradation of estrogen receptor alpha through activation of proteasomes. Mol Cell Biol 2003, 23(6): I843-55.

93. Qin C, Burghardt R, Smith R, Wormke M, Stewart J, Safe S: Peroxisome proliferator-activated receptor gamma agonists induce proteasome-dependent degradation of cyclin DI and estrogen receptor alpha in MCF-7 breast cancer cells. Cancer Res 2003, 63(5):958-64.

94. Cardoso F, Durbecq V, Laes JF, Badran B, Lagneaux L, Bex F, Desmedt C, Willard-Gallo K, Ross JS, Burny A, Piccart M, Sotiriou C: Bortezomib (PS-34I, Velcade) increases the efficacy of trastuzumab (Herceptin) in HER-2-positive breast cancer cells in a synergistic manner. Mol Cancer Ther 2006, 5:3042-5I.

95. Ambrosini G, Adida C, Altieri DC: A novel anti-apoptosis gene, survivin, expressed in cancer and lymphoma. Nat Med 1997, 3(8):9|7-92|.
96. Tanaka K, Iwamoto S, Gon G, Nohara T, Iwamoto M, Tanigawa N: Expression of survivin and its relationship to loss of apoptosis in breast carcinomas. Clin Cancer Res 2000, 6(I):127-134.

97. Xia W, Bisi J, Strum J, Liu L, Carrick K, Graham KM, Treece AL, Hardwicke MA, Dush M, Liao Q, et al.: Regulation of survivin by ErbB2 signaling: therapeutic implications for ErbB2-overexpressing breast cancers. Cancer Res 2006, 66(3): 1640-1647.

98. Ohta T, Michel JJ, Schottelius AJ, Xiong Y: ROCI, a homolog of APCI I, represents a family of cullin partners with an associated ubiquitin ligase activity. Mol Cell 1999, 3(4):535-4I.

99. Kamura T, Koepp DM, Conrad MN, Skowyra D, Moreland RJ, Iliopoulos O, Lane WS, Kaelin WG Jr, Elledge SJ, Conaway RC, Harper JW, Conaway JW: RbxI, a component of the VHL tumor suppressor complex and SCF ubiquitin ligase. Science 1999 , 284(54 | 4):657-6I.

100. Chen C, Seth AK, Aplin AE: Genetic and expression aberrations of E3 ubiquitin ligases in human breast cancer. Mol Cancer Res 2006, 4(I 0):695-707.

101. Early Breast Cancer Trialists' Collaborative Group (EBCTCG): Effects of chemotherapy and hormonal therapy for early breast cancer on recurrence and 15-year survival: an overview of the randomised trials. Lancet 2005, 365(9472): $1687-717$.

102. Perez EA, Hortobagyi GN: Ongoing and planned adjuvant trials with trastuzumab. Semin Oncol 2000, 27(6 Suppl II):26-32.

103. Ruffner H, Joazeiro CA, Hemmati D, Hunter T, Verma IM: Cancerpredisposing mutations within the RING domain of BRCAI: loss of ubiquitin protein ligase activity and protection from radiation hypersensitivity. Proc Natl Acad Sci USA 200I, 98(9):5।34-5।39.

104. Brzovic PS, Keeffe JR, Nishikawa H, Miyamoto K, Fox D 3rd, Fukuda $M$, Ohta $T$, Klevit R: Binding and recognition in the assembly of an active BRCAI/BARD I ubiquitin-ligase complex. Proc Nat Acad Sci USA 2003, 100(10):5646-565I.

105. Morris JR, Pangon L, Boutell C, Katagiri T, Keep NH, Solomon E: Genetic analysis of BRCAI ubiquitin ligase activity and its relationship to breast cancer susceptibility. Hum Mol Genet 2006, 15(4):599-606

\section{Publication history}

Republished from Current BioData's Targeted Proteins database (TPdb; http://www.targetedproteinsdb.com).

Publish with Biomed Central and every scientist can read your work free of charge

"BioMed Central will be the most significant development for disseminating the results of biomedical research in our lifetime. "

Sir Paul Nurse, Cancer Research UK

Your research papers will be:

- available free of charge to the entire biomedical community

- peer reviewed and published immediately upon acceptance

- cited in PubMed and archived on PubMed Central

- yours - you keep the copyright 